\title{
The Effect of Organic Fertilizer Types and Phosphate Fertilizer Doses on Growth and Yield of Chili (Capsicum Annum L.) var. Lotanbar
}

\author{
Helti Andraini ${ }^{1}$, Firsta Ninda Rosadi ${ }^{2}$, and Vivi Ruslini ${ }^{1}$ \\ ${ }^{1}$ Department of Agrotechnology, Faculty of Agriculture, Mahaputra Mubammad Yamin University, Solok, West Sumatra, 27361, \\ Indonesia \\ ${ }^{2}$ Department of Agrotechnology, Faculty of Agriculture, Andalas University, Padang, West Sumatra, 25163, Indonesia
}

\section{Article Info}

Received:

26 February 2021

Accepted:

09 March 2021

Published:

10 March 2021

Competing Interest:

The authors have declared that no competing interest exists.

\section{Corresponding Author:}

Firsta Ninda Rosadi, Department of

Agrotechnology, Faculty of

Agriculture, Andalas University,

Padang, West Sumatra, 25163,

Indonesia

Email: firstanidarosadi@agr.unand.ac.id

(C) 2021 The Authors. This is an open access article under the CC BY license.

\begin{abstract}
Red chili plants are one of the important vegetable commodities and have high economic value in Indonesia. The demand for red chili plants is increasing every year so that efforts are needed to increase productivity. In this study, we used organic fertilizers and inorganic fertilizers to determine the effect of fertilizers interaction and fertilizers optimal dosage on the growth and yield of red chili plants. The design used a factorial design in a Randomized Complete Block Design (RCBD) with 2 factors. The first factor is the type of organic fertilizers. The second factor is the dosage of SP-36 fertilizer as a source of phosphate. Observations data variance were analyzed using the DNMRT at the $5 \%$ significant level. The results showed that the effect of cow manure application was better than the application of straw compost for all observation variables, the optimal dosage of inorganic fertilizer is based on the observed variables, namely at a dose of $30 \mathrm{~g} /$ plant and there is no interaction between types of organic fertilizers and the dosage of phosphate fertilizers.
\end{abstract}

Keywords: organic fertilizer, phosphate fertilizer, plant growth, red chili, yield production 


\section{Introduction}

Chili (Capsicum annum L.) is one of the important vegetable commodities and has a high economic value in Indonesia. Most of its uses are for household purposes and industrial uses. The demand for chili is increasing every year so that efforts are needed to increase the productivity of chili plants (Setiawati, et al., 2007).

Hayati et al. (2012) explored the diversity of chili in Lima Puluh Kota Regency, they found high diversity in chili types grown by farmers. Department of Food Crops and Horticulture of Limapuluh Kota (2015) states that farmers in Kenagarian Talang Maur, Mungka District, Limapuluh Kota Regency found chili plants that have more than one fruit in several nodes, which are named chili var. Lotanbar (Lokal Talang Barangkai). Chili var. Lotanbar is registered by the local government as a high-yielding local chili variety since 2011. Chili var. Lotanbar has different characteristics from other curly red chilies, which have many productive branches and resistant to pests and diseases, such as anthracite and yellow virus. The fundamental specific characteristics are related to the length of the fruit (about 17-24 cm), the length of the shoot, also the harvest period in one season. Chili var. Lotanbar cultivation is also different from other curly red chili cultivation. Chili var. Lotanbar beds are made with a flat surface. Time of sowing the seeds and time of flowering the shoots also different from other red chilies.

One of the efforts to increase chili production is by fertilization. Marlina (2010) reported the use of different manure types affects the production of chili plants is at a dose of 20 ton/ha, and cow manure can increase the growth and yield of chili plants. Merismon (2014) reported that the application of 10 tons/ha of cow manure gives the best results on the growth and production of chili plants. One of the inorganic fertilizers used is phosphate fertilizer. Phosphate is one of the main nutrients which is very important for the growth of chili plants. Phosphate elements play a role in stimulating root growth, especially seed roots and young plants, helping assimilation, accelerating flowering, and seed ripening (Lingga, 2013). Yudha et al. (2014) reported that the effect of phosphate fertilizer up to a dose of $40 \mathrm{~g} /$ plant can increase the growth and production of chili plants linearly in all the observed variables.

The study aimed to determine the effect of the interaction between the application of organic fertilizers and inorganic fertilizers on the growth and yield of red chili plants, then to determine the effect of the type of organic fertilizer and the optimal dosage of inorganic fertilizers on the growth and yield of red chili plants.

\section{Materials and Methods}

The research was conducted from January to May 2019 in Nagari Sumani, X Koto Singkarak District, Solok Regency, which is located at an altitude of \pm 400 $\mathrm{m}$ above sea level. Research materials were seeds of chili var. Lotanbar, soil, cow manure, straw compost, and SP-36 fertilizer as a source of phosphate. The design used a factorial design in a Randomized Complete Block Design (RCBD) with 2 factors. The first factor is the type of organic fertilizers derived from cow manure (A1) and straw compost (A2). The second factor is the dosage of SP-36 fertilizer as a source of phosphate at a dose of $10 \mathrm{~g} /$ plant (B1), a dose of $30 \mathrm{~g} /$ plant (B2), and a dose of $50 \mathrm{~g} /$ plant (B3), each treatment consisting of four sample plants. Observations data were evaluated by analysis of variance if the obtained $\mathrm{F}$ count was greater than $\mathrm{F}$ table $5 \%$ followed by a further test of Duncan New Multiple Range Test (DNMRT) at the 5\% significant level. Observed parameters were plant height, stem diameter, number of fruits, fruit length, fruit weight per plant, and yield of chili per ha.

\section{Results and Discussion}

\section{A. Plant height}

The data of plant height variance showed that there was no interaction between the type of organic fertilizer and the dose of phosphate fertilizer, while the single factor treatment of the type of organic fertilizer had a significant effect and the dose of phosphate fertilizer had no significant effect. The average height of chili plants is presented in Table 1 .

Table 1 shows that the average dosage of phosphate fertilizer does not affect plant height. Although statistically, the application of phosphate fertilizer gave the same effect, the dose of phosphate fertilizer $50 \mathrm{~g} /$ plant had the highest plant height namely $61.89 \mathrm{~cm}$.

Table 1 also shows that the different treatments of organic fertilizers are produced differently in terms of plant heights. The height of the chili plants with the application of cow manure (namely $63.07 \mathrm{~cm}$ ) was higher than chili plants applied by straw compost. The application of manure can increase plant height because of the availability of macronutrients $(N, P$, and $\mathrm{K})$ and micronutrient content which play role in plant growth. Manure also contains organic matter that is needed by plants such as humic acids, fulvic, growth hormones, and other compounds that stimulate plant growth so that nutrient uptake by plants increases.

The increase in plant height is mainly due to Nitrogen $(\mathrm{N})$ because this nutrient is needed by plants in the vegetative phase. 
Table 1. The average height of chili plants $(\mathrm{cm})$ in several types of organic fertilizer treatments and the dosage of SP-36 phosphate fertilizer

\begin{tabular}{ccccc}
\hline $\begin{array}{c}\text { Types of Organic } \\
\text { Fertilizers }\end{array}$ & $\mathbf{1 0} \mathbf{g}(\mathbf{B} 1)$ & $\mathbf{3 0} \mathbf{g} \mathbf{( B 2})$ & $\mathbf{5 0} \mathbf{g}(\mathbf{B} 2)$ & Average \\
\hline Cow manure (A1) & 60.638 & 65.063 & 63.512 & $63.071 \mathrm{a}$ \\
Straw compost (A2) & 57.450 & 54.938 & 60.275 & $57.554 \mathrm{~b}$ \\
Average & 59.044 & 60.000 & 61894
\end{tabular}

$\mathrm{KK}=8.83 \%$

Figures with the same lowercase letters in the same column are not significantly different according to the DNMRT level of $5 \%$.

Cow manure decomposes faster and provides $\mathrm{N}$ nutrients faster in the soil than straw compost (Massa et al., 2016). Nitrogen is needed by plants to stimulate overall growth, especially stems so that they increase in height and diameter. The higher the nitrogen available to plants, the more growth of stems, shoots, and leaves on the plant (Lingga and Marsono, 2007).

\section{B. Fruit length}

Table 2. The average fruit length of chili plants $(\mathrm{cm})$ in several treatments of types of organic fertilizers and dosage of SP36 phosphate fertilizer

\begin{tabular}{ccccc}
\hline $\begin{array}{c}\text { Types of Organic } \\
\text { Fertilizers }\end{array}$ & $\mathbf{1 0} \mathbf{g}(\mathbf{B} 1)$ & $\mathbf{3 0} \mathbf{g} \mathbf{( B 2})$ & $\mathbf{5 0} \mathbf{~} \mathbf{~ ( B 2 )}$ & Average \\
\hline Cow manure (A1) & 17.75 & 18.75 & 18.18 & $18.22 \mathrm{a}$ \\
Straw compost (A2) & 16.75 & 16.88 & 16.50 & $16.71 \mathrm{~b}$ \\
average & 17.25 & 17.81 & 17.34
\end{tabular}

$\mathrm{KK}=24.2 \%$
Data analysis of fruit length and weight variance with the type of organic fertilizer and the dose of phosphate fertilizer demonstrate no significant interaction. While the single factor treatment of the type of organic fertilizer had a very significant effect and conversely, the treatment of phosphate fertilizer had no significant effect. The average fruit lengths and fruit weights of chili plants are presented in Table 2 .

Figures with the same lowercase letters in the same column are not significantly different according to the DNMRT level of $5 \%$

Table 2 shows that although statistically, the length of chilies with different dosages of phosphate fertilizer does not show any significant difference of results, with a dose of $30 \mathrm{~g} /$ plant the longest fruit length is $17.81 \mathrm{~cm}$.

Table 2 also shows the average fruit length of chili with the application of organic fertilizer is very different. The application of cow manure has a fairly high average fruit length (namely $18.22 \mathrm{~cm}$ ) compared to the provision of straw compost which has an average fruit length of $16.71 \mathrm{~cm}$. Based on the Indonesian National Standard No. 01-4480-2016, fruit length with an average of $18 \mathrm{~cm}$ is categorized as Quality I. The application of cow manure increases the length of chilies than the application of straw compost. This is because cow manure can improve conditions environment for plant growth.

Prasetya (2014) and Marsono dan Sigit (2008) stated that cow manure can increase soil structure for root development, increase grip and the absorption of soil to water, improve the life of the organism in the soil, and add soil nutrients. According to Hajadi (2012), fruit formation and filling are strongly influenced by macronutrients $(\mathrm{N}, \mathrm{P}$, and $\mathrm{K}) . \mathrm{N}, \mathrm{P}$, and $\mathrm{K}$ are used in the photosynthesis process as a constituent of carbohydrates, fats, proteins, minerals, and vitamins which will be translocated to the storage of fruit.

\section{Fruit weight per plant}

Data analysis of fruit weight variance with the type of organic fertilizer and the dose of phosphate fertilizer show no significant interaction. While the single factor treatment of the type of organic fertilizer had a very significant effect and the treatment of phosphate fertilizer had no significant effect. The average fruit weights of chili plants are presented in Table 3. 
Table 3. The weight of chilies per plant (grams) in several types of organic fertilizer treatments and the dosage of SP-36 phosphate fertilizer

\begin{tabular}{ccccc}
\hline $\begin{array}{c}\text { Types of Organic } \\
\text { Fertilizers }\end{array}$ & $\mathbf{1 0} \mathbf{g ~ ( B 1 )}$ & $\mathbf{3 0} \mathbf{g ~ ( B 2 )}$ & $\mathbf{5 0} \mathbf{~} \mathbf{~ ( B 2 )}$ & Average \\
\hline Cow manure (A1) & 25.053 & 26.592 & 22.335 & $24.660 \mathrm{a}$ \\
Straw compost (A2) & 17.130 & 14.915 & 16.748 & $16.264 \mathrm{~b}$ \\
average & 21.092 & 20.753 & 19.542
\end{tabular}

$\mathrm{KK}=20.18 \%$

Figures with the same lowercase letters in the same column are not significantly different according to the DNMRT level of 5\%

Table 3 shows the average fruit weight per plant at the dose of phosphate fertilizer is not much different. The average at a dose of $10 \mathrm{~g} / \mathrm{plant}$ is $21.09 \mathrm{~g}, 30$ $\mathrm{g} /$ plant $20.75 \mathrm{~g}$, and $50 \mathrm{~g} /$ plant $19.54 \mathrm{~g}$.

Table 3 also shows that the cow manure treatment produced the most average fruit weight per plant $(24.66 \mathrm{~g})$, which was very significantly different from the average weight of chilies obtained from the straw compost fertilizer treatment $(16.26 \mathrm{~g})$. Moekasan (2012) states that to get a high fruit weight, a sufficient amount of photosynthate must be available through the photosynthesis process and translocated to the recipient organs (flowers and fruit), then to get large fruit, cell division must occur accompanied by cell enlargement.

\section{The yield of chili per hectare}

There is an interaction between the treatment of types of organic fertilizers and the dosage of phosphate fertilizers on the yield of chili plants per hectare as presented in Table 4.

Table 4. The yield of chili plants (ton/ha) in several interactions between types of organic fertilizers and dosage of SP-36 phosphate fertilizer

\begin{tabular}{cc} 
Treatment Combination & The yield of chili plants (ton/ha) \\
\hline A1B1 & $7,514 \mathrm{~b}$ \\
A1B2 & $7,978 \mathrm{a}$ \\
A1B3 & $6,700 \mathrm{c}$ \\
A2B1 & $5,134 \mathrm{~d}$ \\
A2B2 & $4,474 \mathrm{e}$ \\
A2B3 & $5,024 \mathrm{f}$
\end{tabular}

$\mathrm{KK}=21,35 \%$

Figures with the same lowercase letters in the same column are not significantly different according to the DNMRT level of 5\%

The highest yield of chili plants was obtained due to the effect of organic fertilizer, namely the A1B2 treatment which produced chili as much as 7,978 tons/ha. Significantly different from the A2B2 treatment which has a very low chili production, namely 4,474 tons/ha. Several studies have proven that the use of organic fertilizers can reduce the number of inorganic fertilizers (Herdiyanti, et al. 2015). Saha et al. (2013) added that the application of organic fertilizers in combination with inorganic fertilizers can not only save the use of inorganic fertilizers and prevent nutritional imbalances but also reduce the risk of environmental pollution, increase soil fertility and increase crop yields. The addition of organic fertilizers containing microorganisms such as $\mathrm{N}$-fixers and $\mathrm{P}$ solvents can reduce the use of inorganic fertilizers by up to $50 \%$ (Herdiyanti, et al. 2015). The results of the research reported by Onggo (2004) and Addieny (2011) state that organic fertilizers enriched with microbe activators can increase yields in tomato and chili plants. The use of organic fertilizers is beneficial for increasing agricultural production both in quality and quantity, reducing environmental pollution, and sustainably improving land quality. The use of organic fertilizers in the long term can increase land productivity and can prevent land degradation. 


\section{Conclusions}

The results showed that the application of organic fertilizers providing better growth and yield of chili var. Lotanbar plants in comparison to inorganic fertilizer. The application of cow manure can increase the growth of plant height, fruit length, fruit weight per plant, and plant yield per ha. The optimal dosage of inorganic fertilizer is based on the observation variables, namely at a dose of $30 \mathrm{~g} /$ plant. Then, there is no interaction between types of organic fertilizers and the dosage of phosphate fertilizers.

\section{Acknowledgment}

The authors thank Mahaputra Muhammad Yamin University for funding this research through DIPA 2019 and thank all people who give help in this research.

\section{Reference}

[1] Addieny, L. 2011. Efektivitas penggunaan pupuk organik yang diperkaya mikrob aktivator dalam mengatur keseimbangan tajuk dan akar tanaman cabai (Capsicum annuum L.). Skripsi. IPB. Bogor.

[2] Badan Standarisasi Nasional. 2016. SNI cabai merah. Badan Standarisasi Nasional. Jakarta. 15 pages.

[3] Dinas Pertanian Tanaman Pangan dan Hortikultura Lima Puluh Kota, 2015. Laporan tahunan Dinas Pertanian, Tanaman Pangan dan Hortikultura Kabupaten Lima Puluh Kota. Kabupaten Lima Puluh Kota.

[4] Hajadi, S. S. 2012. Dasar-dasar agronomi. Jakarta: Gramedia. 85 pages.

[5] Hayati, E., T. Mahmud, and R. Fazi. 2012. Pengaruh jenis pupuk organik dan varietas terhadap pertumbuhan dan hasil tanaman cabai. J. Floratek, 7: 173-181.

[6] Herdiyanti, T., Sugiyanta, and H. Aswandinnoor. 2015. Tanggap tiga varietas padi sawah terhadap kombinasi pemupukan dengan sistem pembenaman jerami. J. Agron. Indonesia, 43(3): 179-185.

[7] Lingga P. dan Marsono. 2007. Petunjuk Penggunaan Pupuk. Edisi Revisi. Jakarta. Penebar Swadaya.

[8] Lingga, P. 2013. Membuat Kompos. Cetakan Ke Enam. PT. Swadaya. Jakarta.

[9] Marlina, N. 2010. Pemanfaatan jenis pupuk kandang pada cabai merah (Capsicum annum). Jurnal Pemanfaatan Jenis Pupuk. Kandang.

[10] Marsono and P. Sigit. 2008. Pupuk Akar Jenis dan Aplikasi. Penebar Swadaya. Jakarta.

[11] Massa, S., Y. Setiyo, and I. W. Widia. 2016. Pengaruh perbandingan jerami dan kotoran sapi terhadap profil suhu dan karakteristik pupuk kompos yang dihasilkan. Jurnal BETA (Biosistem dan Teknik Pertanian), 4(2): 69-75.

[12] Merismon. 2014. Pertumbuhan dan hasil tanaman cabai besar (Capsicum annum L.) di tanah gambut yang diberi pupuk kandang kotoran sapi. Prosiding Seminar Nasional Lahan Suboptimal 2014. Palembang 26-27 September 2014.

[13] Moekasan, T. K. 2012. Penggunaan rumah kasa untuk mengatasi serangan organisme penganggu tumbuhan pada tanaman cabai merah di dataran rendah. Indonesian Center for Horticulture Research and Development.

[14] Onggo, T. M. 2004. Aplikasi Bioaktivator dan Pengaruhnya Terhadap Pertumbuhan dan Hasil Berbagai Sayuran.

[15] Prasetya, M. E. 2014. Pengaruh pupuk NPK Mutiara dan pupuk kandang sapi terhadap pertumbuhan dan hasil tanaman cabai merah keriting varietas Arimbi (Capsicum annum L.). Jurnal AGRIFOR , 13(2): 191-198.

[16] Saha, R., M. A. U. Saieed, and M. A. K. Chowdhury. 2013. Growth and yield of rice (Oryza sativa) as influenced by humic acid and poultry manure. Universal J. Plant Sci., 1:78-84.

[17] Setiawati, W., R. Murtiningsih, G. A. Shopa, and T. Handayani. 2007. Petunjuk teknis budidaya tanaman sayuran. Balai Penelitian Tanaman Sayuran, Pusat Penelitian dan Pengembangan Hortikultura, Badan Penelitian dan Pengembangan Pertanian. 135 pages.

[18] Yudha, P. K. S., M. S. Hadi and Y. C. Ginting. 2014. Pengaruh tiga jenis pupuk kandang dan dosis pupuk fosfat pada pertumbuhan dan produksi tanaman cabai (Capssicum annum L.). J. Agrotek Tropika, 2(1): 95 - 102. 